\title{
SINKHOLE CLUSTERS AFTER HEAVY RAINSTORMS
}

\author{
Mario Parise ${ }^{1,2, \mathrm{C}}$, Luca Pisano ${ }^{2}$, and Carmela Vennari ${ }^{2,3}$
}

\begin{abstract}
Sinkholes are the most common geological hazard in karst terrains. Generally triggered by rainstorms or by changes in the hydrological/hydrogeological regime, they display a wide range of morphologies and sizes. Typically, the main difficulty in evaluating the sinkhole hazard is represented by the collection of reliable data about time of occurrence of the events, which is a mandatory requirement for the estimation of the hazard. In this paper, we document a dozen sinkholes triggered by a heavy rainstorm that occurred during the first week of September 2014 in the Gargano Promontory of Apulia (southeastern Italy). Following a description of the rainstorm, two clusters of sinkholes are described, starting with the identification of the sinkhole type and of the main morphometric characteristics. Even though it is very likely that the documented sinkholes are only a fraction of those caused by the September 2014 rainstorm, this documentation provides insights for the collection of important sinkhole data produced by a specific, triggering storm.
\end{abstract}

\section{Introduction}

Sinkholes (or dolines) are closed depressions with internal drainage, widely regarded as one of the main diagnostic landforms of epigenic karst (Ford and Williams, 2007; Palmer, 2007; Gutiérrez, 2010; De Waele et al., 2011). Sinkholes display a wide range of morphologies (cylindrical, conical, bowl- or pan-shaped), varying in size up to hundreds of meters across and typically from a few to tens of meters deep (Gutiérrez et al., 2008, 2014). The origin of a sinkhole can be natural, if related to the presence of soluble rocks, or anthropogenic. In this latter case, anthropogenic sinkholes indicate a connection to a man-made underground cavity (De Bruyn and Bell, 2001; Parise and Gunn, 2007; Waltham and Lu, 2007; Parise, 2012, 2015).

Natural sinkholes are typically triggered by rainfall events and by the consequent effect these events might have on groundwater circulation (White and White, 1984; Kovačič and Ravbar, 2010; Lei et al., 2016). Another significant trigger is seismic shocks, which may work in creating new sinkholes, or in enlarging those already existing (Kawashima et al., 2010; Parise et al., 2010; Borgatti et al., 2013).

Sinkholes are typically described by their spatial distribution and density (Day, 1983; Hung et al., 2002; Angel et al. 2004; Gao et al., 2005; Kemmerly, 2006; Lyew-Ayee et al., 2006; Bautista et al., 2011), in relation to the built-up environment (He et al., 2003; Scheidt et al., 2005; Brinkmann et al., 2008; Cooper, 2008), or to geological and morphological settings (Panno et al., 1994; Denizman, 2003; Florea, 2005; Del Prete et al., 2010; Basso et al., 2013; Fragoso-Servón et al., 2014), often without entering into specific details about date of occurrence. Other studies focus on the integration of different approaches, for the identification of the sinkhole-prone areas, from stratigraphy to geophysical techniques, to the use of digital elevation models (Ezersky et al., 2009; Frumkin et al., 2011; Margiotta et al., 2012, 2016; Miao et al., 2013; Wu et al., 2016).

Detailed documentation about sinkholes, aimed at ascertaining their direct relationships with the triggering factor (rainfall, earthquake, etc.), is not always easily accessible in the scientific literature. With the exception of some states in the United States (namely, Florida, Kentucky and Illinois, where there is high awareness about sinkhole problems; see in this regard, White et al., 1986; Tihansky, 1999; Brinkmann et al., 2007, 2008; Brinkmann, 2013, and references therein; Polk et al., 2015), in the rest of the world, attention toward sinkholes is typically not so high. It is definitely lower than that paid to other geological hazards such as landslides, floods, or tsunamis. Post-event sinkhole surveys rarely have the amount of information necessary to fully link each event to its precise time of occurrence. This often represents the main drawback in the process of sinkhole hazard evaluation, as knowledge of the temporal occurrence is mandatory at this goal (Gutierrez-Santolalla et al., 2005; Farrant and Cooper, 2008; Galve et al., 2011; Heidari et al., 2011).

Even if sinkhole occurrence in Italy is not frequent, when compared to other geological hazards such as landslides or floods, there are many regions highly prone to these events due to the widespread presence of carbonate or evaporite rocks. These rocks are highly susceptible to dissolution processes, which may be locally enhanced or favored by a number of human activities (lovine et al., 2010, 2016; Vigna et al., 2010; Parise, 2012; Zini et al., 2015; De Waele et al., 2017). Within the framework of a project by the Institute of Research for Geo-Hydrological Protection of the National Research Council of Italy (CNR IRPI), dedicated to evaluation of natural and anthropogenic hazards in karst, Parise and Vennari (2013) built a chronological database on sinkhole occurrence in Italy that contains information about sinkholes. These include morphometric data, damage, and triggering factors. In this database, sinkholes are divided on the

\footnotetext{
${ }^{1}$ Department of Earth and Environmental Sciences, University Aldo Moro, Bari, Italy

${ }^{2}$ National Research Council, Institute of Research for Geo-Hydrological Protection, Bari, Italy

${ }^{3}$ Department of Earth Sciences, University “Federico II," Naples, Italy

${ }^{c}$ Corresponding Author: mario.parise@uniba.it
} 


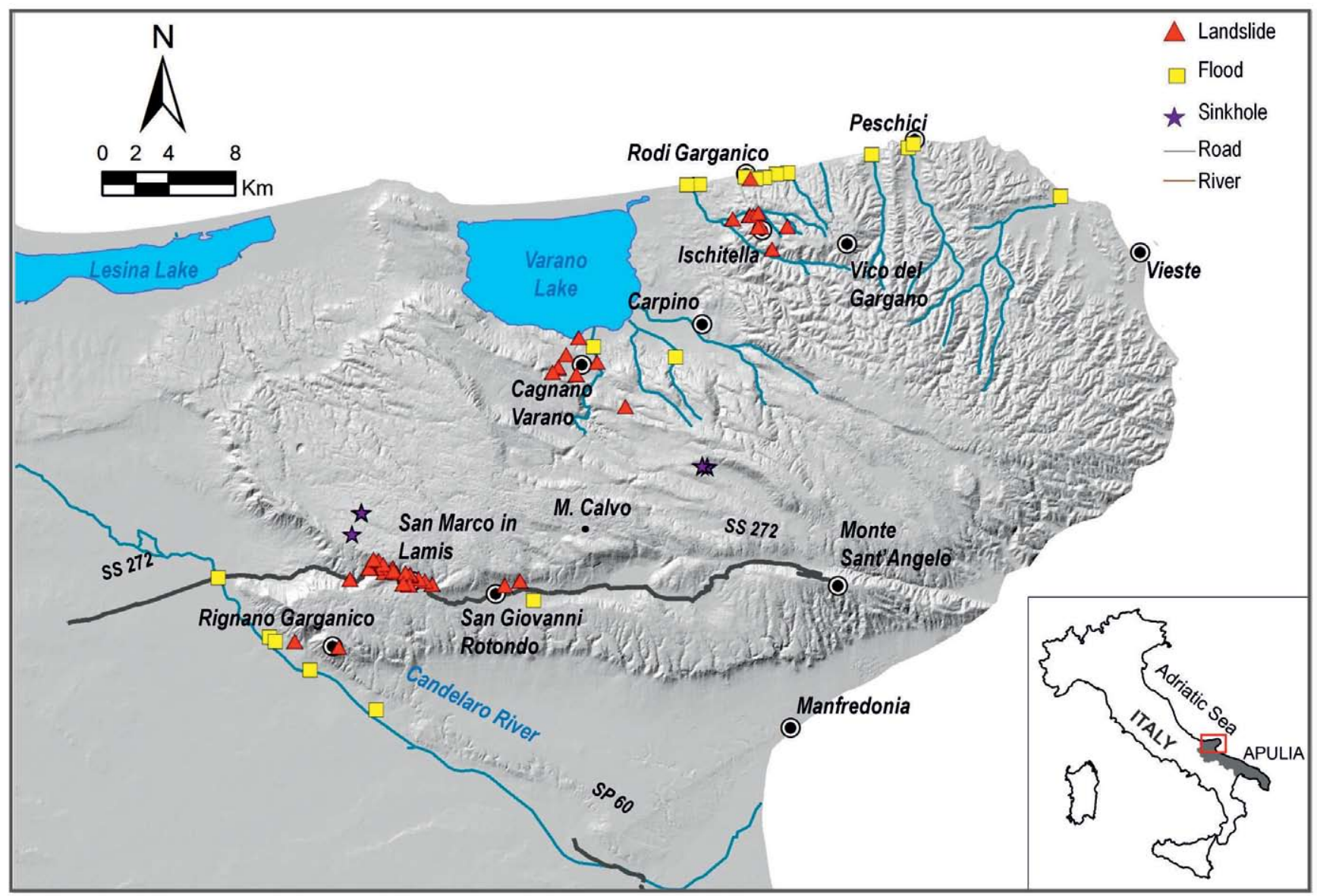

Figure 1. Map showing location of the study area and the events triggered by the September 1-6, 2014, intense rainfall event in the Gargano Promontory.

basis of cave origin: natural or anthropogenic. Time of occurrence and location of sinkholes are known for every event, with different levels of accuracy and certainty, based upon a careful examination of the information source from each event.

In this paper, aimed at contributing to increase the documentation between sinkholes and triggering factors, we present data about a number of sinkholes that occurred, together with other geological hazards such as landslides and floods (Fig. 1), in consequence of the rainstorm that hit the Gargano Promontory in northern Apulia, during the first week of September 2014. We are strongly convinced that availability of a large amount of reliable information about sinkhole occurrence, and their main morphometric features at the time of the formation, is a fundamental piece of evidence contributing to properly move toward assessment of the sinkhole hazard. With such a goal, we document and describe the observed sinkholes to improve the available sinkhole data from the karst of Apulia.

\section{Sinkholes in Apulia}

In the CNR IRPI database (Parise and Vennari, 2013), the Apulia region (southeastern Italy) is one region with the highest sinkhole occurrence (Delle Rose and Parise, 2002; Bruno et al., 2008; Fidelibus et al., 2011; Festa et al., 2012; Margiotta et al., 2012). Sinkholes have repeatedly caused serious damage to infrastructures and buildings, but above all, to human life (Parise and Lollino, 2011), with more than 650 evacuees and injured, and one victim reported. For example, 140 events have been collected from 1925 to 2017 in Apulia, 85 that have an anthropogenic origin, while 50 are related to the presence of a natural cavity (Fiore and Parise, 2013; Parise and Vennari, 2013, 2017; Lollino et al., 2013). The remaining events are with "unknown origin," meaning that the presence of an underground cavity is clear, but no certain data about the sinkhole origin is available.

Sinkhole occurrences in Apulia represent a serious geological hazard (Fig. 2), for which it is essential to have a complete knowledge of the cause. To properly evaluate such a hazard, it is necessary to reach a good understanding of the development and type of the caves at the sinkhole origin, and their stability conditions (Parise, 2010). Most of the sinkholes that produced damage are related to man-made underground cavities. Anthropogenic cavities are widespread in Apulia. They have been excavated since ancient time, due to distinct but complementary needs: urban development demanding building materials; and the necessity to keep developing agricultural practices at the surface, 
Figure 2. Spatial distribution of sinkholes in Apulia Region (data from CNR IRPI catalogue, updated to January 2017). The different origin of sinkholes is marked by different colors (see key). The inset horizontal histogram shows percentages of sinkholes for the different origins.

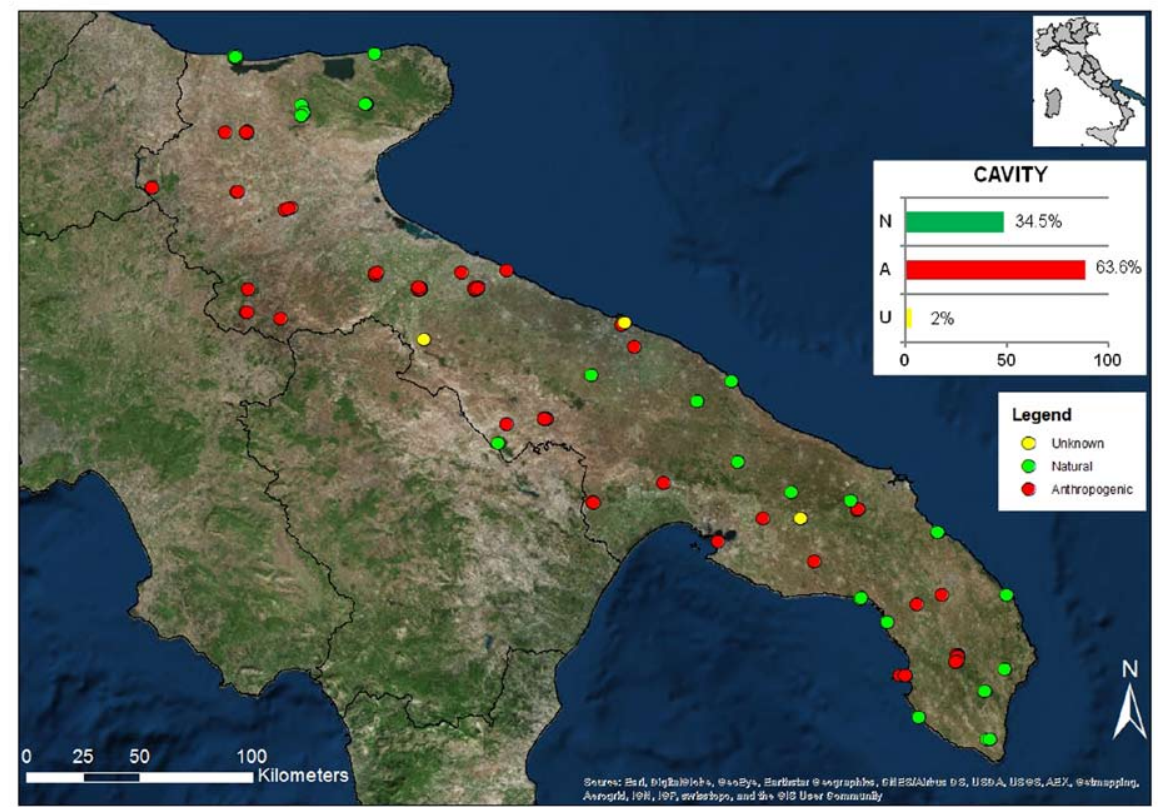

in a land where products such as olive oil and wine have always been important (Parise, 2010; Negri et al., 2015).

The temporal distribution of sinkholes in Apulia during the period analyzed shows an increase of events in recent decades. The number of sinkhole occurrences in the last five years is higher than the other periods (Fig. 3). This is due to a growing availability of sinkhole data in scientific documents. Also, increasing attention is given to these phenomena, as more sinkhole information is published in the media. The number of sinkhole occurrences has grown. In particular, the number of events linked to natural caves is rising over the last decade. Anthropogenic sinkhole occurrences have gone down since 2010 .

The most affected province by sinkhole is Foggia, in northern Apulia. Sinkholes can be triggered by several causes, both of natural and man-induced origin. Maintenance works, or a pipeline rupture can activate the event. However, the main triggering factor is rainfall, due to dissolution processes that can produce a sinkhole.

\section{Materials and Methods}

Aimed at characterizing the sinkholes formed in Gargano during the September 2014 storm, the rainfall data were collected, taking into account records from the available rain gauges closest to the sinkhole occurrence sites. They were analyzed to identify the rainfall intensity during different phases of the storm, and to evaluate rainfall intensity values and duration with respect to the average area rainfall.

The two clusters of sinkholes produced by the rainstorm - due to small size of the features and to unavailability of post-storm aerial photos - were analyzed by collecting geological and morphometric data through field surveys. For each sinkhole, several morphometric parameters were measured, following the classical studies about sinkhole morphometry. These included parameters such as diameter, shape and depth, sinkhole location in geomorphological unit at larger scale, and observations on the geological materials exposed along the sinkhole walls. Data from caving surveys were further obtained from local cavers. The data were field-checked, and discussed with the surveyors, to integrate additional data from underground explorations.

The data collection phase was important to record these small-size sinkholes, which are easily filled up or covered by vegetation, probably with the exception of the largest ones. In the process of sinkhole hazard evaluation, the collection of detailed sinkhole data linked to a specific triggering event - in this case, the September 2014

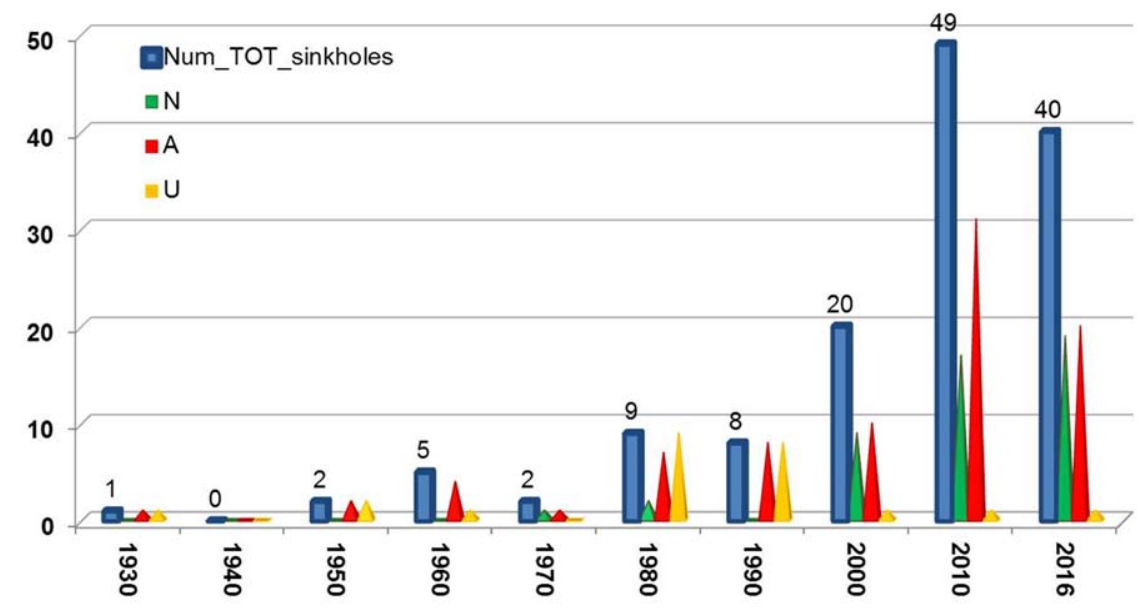

Figure 3. Time distribution of sinkholes in Apulia Region. Blue bars are the total number of sinkholes, green pyramids are natural sinkholes $(\mathrm{N})$, red pyramids are anthropogenic sinkholes $(A)$, yellow pyramids are sinkholes with unknown origin $(U)$. 
storm - represents a set of highly valuable information addressed toward a proper assessment of the return time of such events, and their relation with particular values of rainfall intensity or of cumulated rainfall.

\section{Results}

Morphology of the Gargano Promontory is mostly controlled by E-W and NW-SE-trending faults (Funiciello et al., 1991; Gambini and Tozzi, 1996; Brankman and Aydin, 2004). Karst is well-developed over the entire area, as well as in the rest of the region: the main karst features are represented by a multitude of sinkholes, reaching a maximum density of up to 100 per square kilometer in the Chiancate area (Castiglioni and Sauro, 2000; Simone and Fiore, 2014). Due to widespread outcroppings of soluble rocks (Bosellini et al., 1999), surface hydrography is limited to a few, short, ephemeral drainages along slopes that bound the elevated central plateau (reaching $1000 \mathrm{~m}$ a.s.l.) and to minor drainages in the alluvial and coastal plains surrounding the Gargano Promontory.

As concerns the September 1-6, 2014, rainstorm, 12 small sinkholes have been documented near the villages of Monte Sant'Angelo and San Marco in Lamis. This is certainly a conservative estimate, since the particularly dense forests covering large portions of Gargano make difficult the identification of such features, especially when small. Nevertheless, two sinkhole clusters have been identified and are described below. Due to the remote areas, where most sinkholes developed and the difficulty to detect them, no precise information is available on the time or period of sinkhole occurrence. We could only state that they were related to the September 1-6 rainstorm, based upon local witnesses. Morphology and shape of the documented features indicate an origin as collapse or cover-collapse sinkholes (Gutiérrez et al. 2008, 2014).

\section{Storm Event Description}

During the first week of September 2014, a complex, long-lasting rainstorm occurred in large sectors of the Apulia Region, with the most intense rainfall being registered in the Gargano Promontory. It was due to a vortex of low pressure that remained stationary for several days between the lower Adriatic Sea and the Balkans Area.

In particular, on September 1, 2014, a cold front coming from northern Europe moved to lower latitudes and caused scattered precipitation along the Apulia peninsula. In the following days, this cold front fueled the low-pressure vortex and, given the particular weather conditions, remained blocked until September 6, creating a prolonged instability, mainly on the Gargano area. This instability was powered by the thermal contrast between cooler air present in the vortex, from NE, and the lower warm and humid layers of the atmosphere in contact with the Adriatic Sea (Martinotti et al., 2015). Total rainfall measured during the event (September 1-6), in terms of cumulated rainfall, was especially high, with a peak of over $500 \mathrm{~mm}$ on some sectors of Gargano (Fig. 4).

The rain gauges located in Cagnano Varano, San Marco in Lamis and San Giovanni Rotondo (Fig. 5a) allowed to derive a cumulated rainfall chart that highlights how the heavy rainfall persisted for the entire week (Figs. 5b, c, d). It shows that the whole area was not hit at the same time: in San Giovanni Rotondo and San Marco in Lamis, the rainfall intensity was almost steady starting from September 3, while in Cagnano Varano two main, distinct rainfall events can

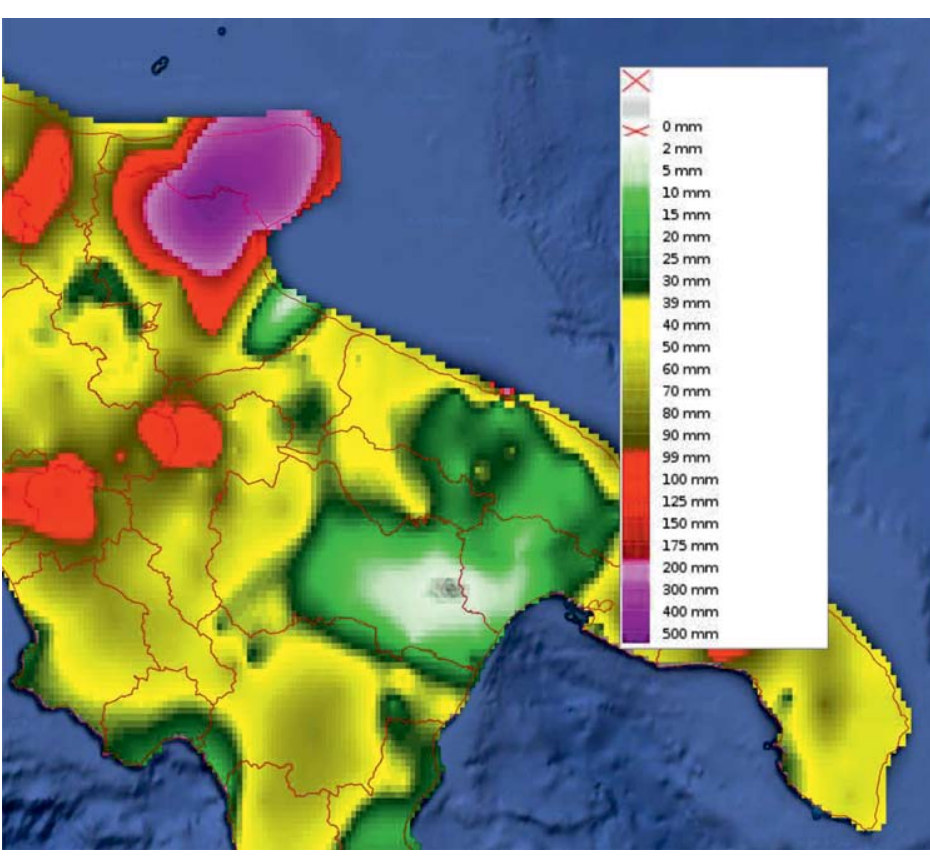

Figure 4. Cumulated rainfall for the whole event, from September 1-6, 2014 (source: Civil Protection Service of Apulia Region). be identified: namely, in the morning of September 4, and on September 6. Maps of cumulated daily rainfall (Fig. 6) highlight how the maximum values during September 3-4 are concentrated in the central area of the Gargano Promontory, while those during September 5-6 are focused in the NE sector. Severity of the storm event is particularly indicated by the fact that the majority of the rain gauges documented the maximum, cumulated rainfall ever registered in a period of five days (Table 1).

\section{Observed Sinkholes}

Sinkholes that occurred in Gargano are natural events quite common in karst areas (Parise, 2008; Gutierrez et al., 2014; Parise et al., 2015a), as a result of intense or prolonged rainfall events that increase the surface and underground outflow. The outflow speed of large water quantities may be able to remove unconsolidated soil, creating new paths for underground water circulation. As consequence, the surface material will collapse in the underlying cavities or karst conduits (Parise et al., 2015b).

During the heavy rainfall event in September 2014, 
several sinkholes occurred in the Gargano Promontory. Twelve sinkholes have been documented and became the object of surveys and measurements. They are likely only a small percentage of the events effectively triggered by the rainstorm, but the extremely dense forest covering large sectors of Gargano obscured sinkhole occurrences.

The documented sinkholes are grouped in two clusters, one in a rural area north of Monte Sant'Angelo, and the other in a small area near the village of San Marco in Lamis. Their main features are reported in Table 2, while in the following we provide a more detailed description.

Sinkholes at Monte Sant'Angelo were observed in a rural area north of the village: six sinkholes, linked to natural cavities, were documented in an area extending about $1500 \mathrm{~m}^{2}$. Based upon the testimonies of local people, they were activated during the September 2014 storm and subsequently were slightly enlarged. In the Bosco Quarto area, terra rossa deposits, ranging in thickness from a few decimeters to several meters, cover the limestone, karstified bedrock - a situation very common in Gargano, as well as in the Murge sub-karst area of central Apulia.

One sinkhole (No. 1, Table 2; Fig. 7c) is included within the limits of a larger solution doline, while most of the others are small openings in the ground (Nos. 2 and 3, Table 2; Fig. 7d), or slight depressions of limited size (the sinkhole pair No. 5 and 6, Table 2; Fig. 7e). The largest sinkholes (No. 4, Table 2; Figs. 7a, b) appeared to be deep (from the surface), $25.2 \mathrm{~m}$, and large $12 \mathrm{~m}$. Actually, speleological survey showed that after the first pit, visible from the ground, a passage allows access to other, deeper spaces, until reaching the maximum depth of $120 \mathrm{~m}$ (Figs. 8 and 9). The cave is vertically developed, and the bad conditions of the hosting rocks (characterized by several joint families and intense weathering, with the likely detachment of rocks) make the descent quite difficult. At the ground surface, the original circular shape of the sinkhole was later modified by secondary enlargements, due to minor failures involving the extremely steep to vertical walls. At least two more sinkholes have been recorded in the surroundings of Monte Sant'Angelo, but they were filled in by landowners before it was possible to observe, measure and document them.

Additional sinkholes were triggered in the village of San Marco in Lamis, again concentrated in a cluster (Figs. 10 and 11). This second cluster of sinkholes mostly affected the epikarst (Klimchouk, 2000; Williams, 2008), consisting of
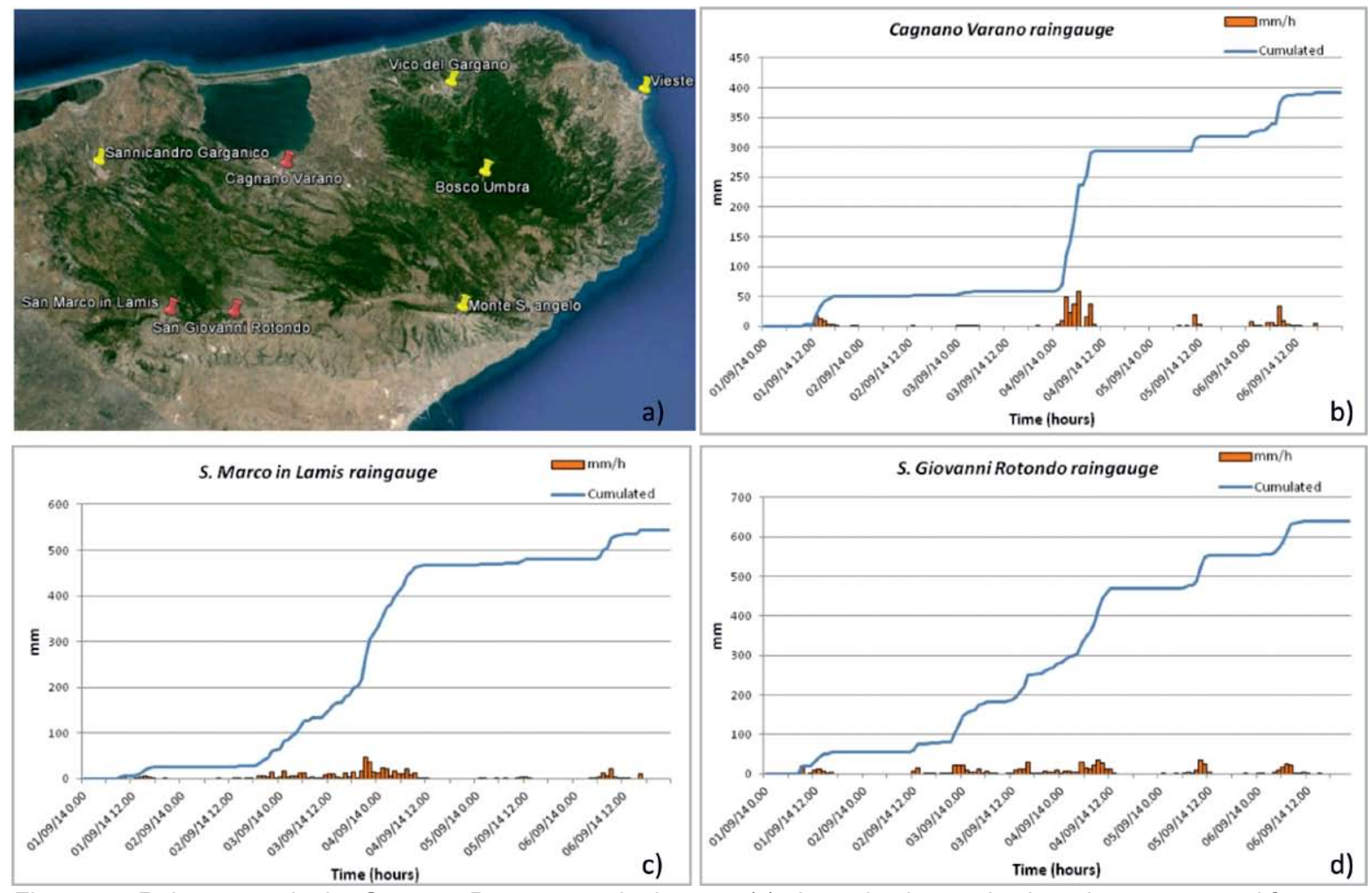

Figure 5a. Rain gauges in the Gargano Promontory. In the map (a), the red color marks the rain gauges used for reconstruction of the rainfall histograms, respectively shown in Figures $5 b, c, d$. 
Figure 6. Cumulated daily rainfall registered during the first week of September, 2014 in the area (source: Civil Protection Service of Apulia Region). Key for colors as in Figure 4.
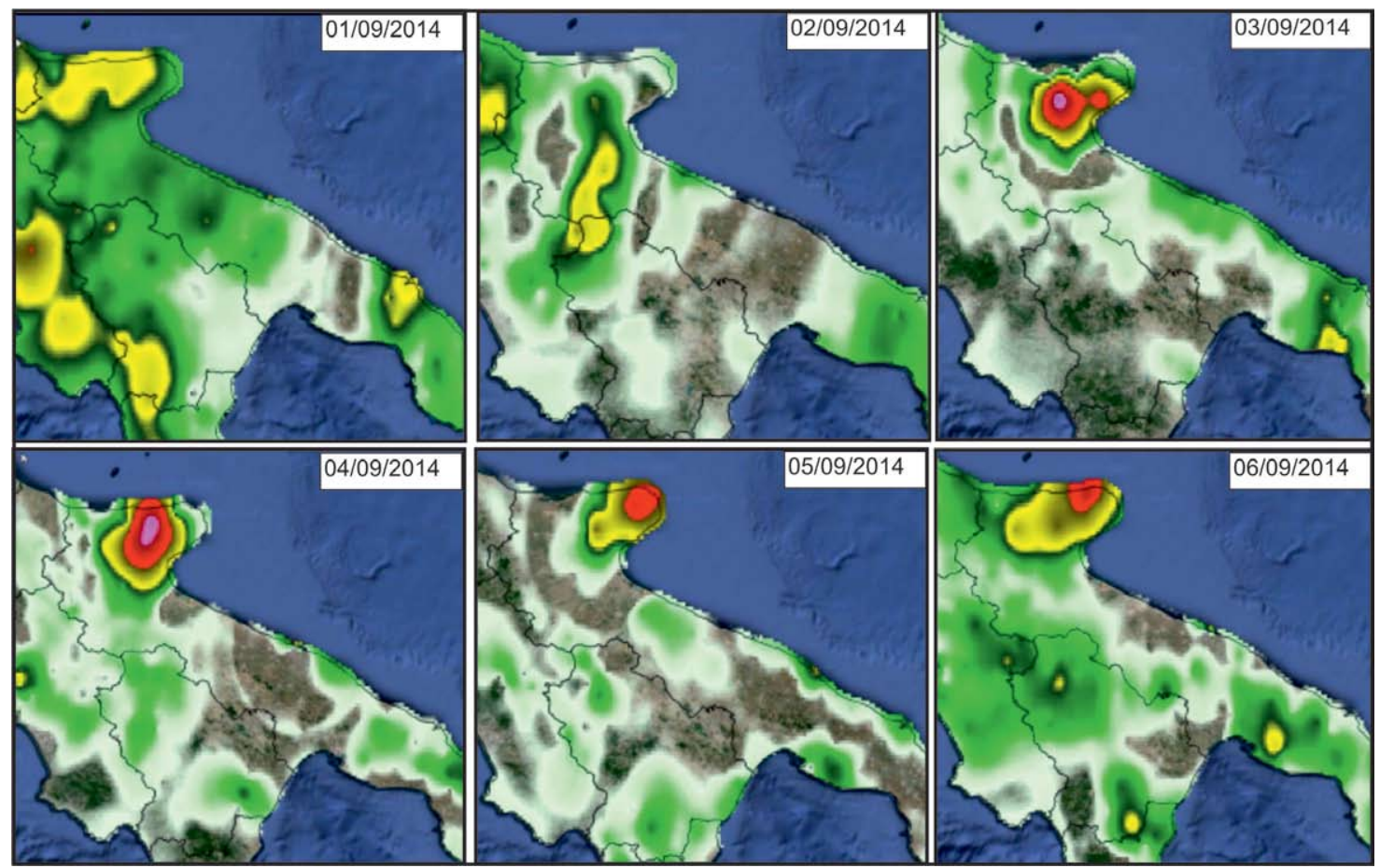

limestone rocks and pinnacles, immersed in terra rossa deposits. Five natural sinkholes were created (Fig. 11). In particular, four of them affect the lower sector of a large karst depression. The features' shapes are predominantly circular, but the dimensions are quite assorted. The smallest sinkhole has a diameter of $1.5 \mathrm{~m}$ and a depth of $1.5 \mathrm{~m}$ (No. 11, Table 2; Fig. 10d). It is placed along the boundary of a wider feature, outlined by circular cracks on the ground. This feature did not open as a true sinkhole. On the other hand, the biggest sinkhole (No. 8, Table 2; Figs. 10, 11a, c) has a diameter of $6 \mathrm{~m}$ and it is $5.4 \mathrm{~m}$ deep. At the base of this sinkhole, the presence of karst conduits (not accessible by man due to the small size), testify to the occurrence of subsurface flow, with likely removal of material, which left unsupported soil above, leading to sinkhole formation. Morphometry and shape of most of the observed sinkholes indicates that they belong to the typologies of collapse or cover-collapse sinkholes (Waltham et al., 2005; Gutierrez et al., 2014).
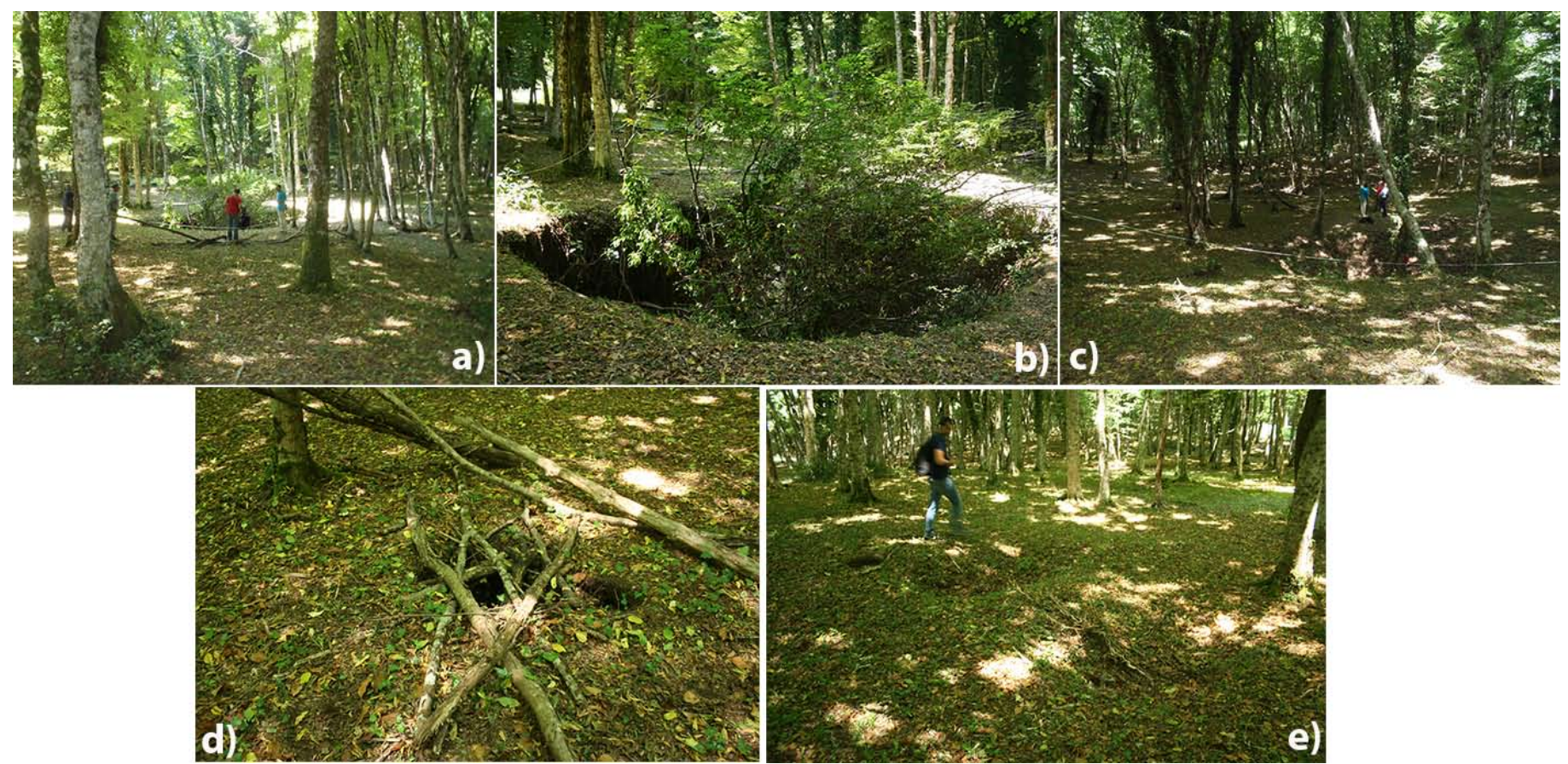

Figure 7. Sinkholes triggered by the September 1-6, 2014, intense rainfall event in the Gargano Promontory at Monte Sant'Angelo: a) approaching the Abisso San Matteo sinkhole (person for scale); b) close up of the entrance at Abisso San Matteo sinkhole (10.2 $\times 12 \mathrm{~m}$ wide); c) $2 \mathrm{~m}$ deep sinkhole; d) small sinkhole, covered by tree branches $(1 \times 1.5 \mathrm{~m}$ wide); e) couple of small-sized and slightly visible ground depressions, nearby the Abisso San Matteo sinkhole (person for scale). 
Table 2. Morphometric data of documented sinkholes triggered by the September 1-6, 2014 intense rainfall event in the Gargano Promontory.

\begin{tabular}{|c|c|c|c|c|c|c|}
\hline No. & Site & Depth, m & Width, m & Shape & Notes & Type \\
\hline 1 & Bosco Quarto, Monte Sant'Angelo & 1.5 & $3 \times 1.5$ & circular & \multirow{10}{*}{$\begin{array}{l}\text { close, likely } \\
\text { connected, to \# } 6 \\
\text { close, likely } \\
\text { connected, to \# } 5\end{array}$} & collapse sinkhole \\
\hline 2 & Bosco Quarto, Monte Sant'Angelo & 3.3 & $1 \times 0.4$ & elongated & & cover-collapse sinkhole \\
\hline 3 & Bosco Quarto, Monte Sant'Angelo & 0.5 & $1 \times 1.5$ & circular & & cover-collapse sinkhole \\
\hline 4 & Bosco Quarto, Monte Sant'Angelo & 120 & $10.2 \times 12$ & circular & & collapse sinkhole \\
\hline 5 & Bosco Quarto, Monte Sant'Angelo & 0.4 & $2 \times 2$ & circular & & cover-collapse sinkhole \\
\hline 6 & Bosco Quarto, Monte Sant'Angelo & 0.4 & $1.5 \times 1.5$ & circular & & cover-collapse sinkhole \\
\hline 7 & Cime-Bosco Rosso, San Marco in Lamis & 5 & $4 \times 3$ & circular & & cover-collapse sinkhole \\
\hline 8 & road San Marco in Lamis - Sannicandro Garganico & 5.4 & $5.7 \times 6$ & circular & & cover-collapse sinkhole \\
\hline 9 & road San Marco in Lamis - Sannicandro Garganico & 6.3 & $2.7 \times 2$ & elliptical & & cover-collapse sinkhole \\
\hline 10 & road San Marco in Lamis - Sannicandro Garganico & 1 & $5.5 \times 5$ & circular & & cover-collapse sinkhole \\
\hline 11 & road San Marco in Lamis - Sannicandro Garganico & 1.5 & $1.5 \times 1.5$ & circular & \multirow[t]{2}{*}{ within a larger doline } & cover-collapse sinkhole \\
\hline 12 & road San Marco in Lamis - Sannicandro Garganico & 3.5 & $1.8 \times 2$ & circular & & cover-collapse sinkhole \\
\hline
\end{tabular}

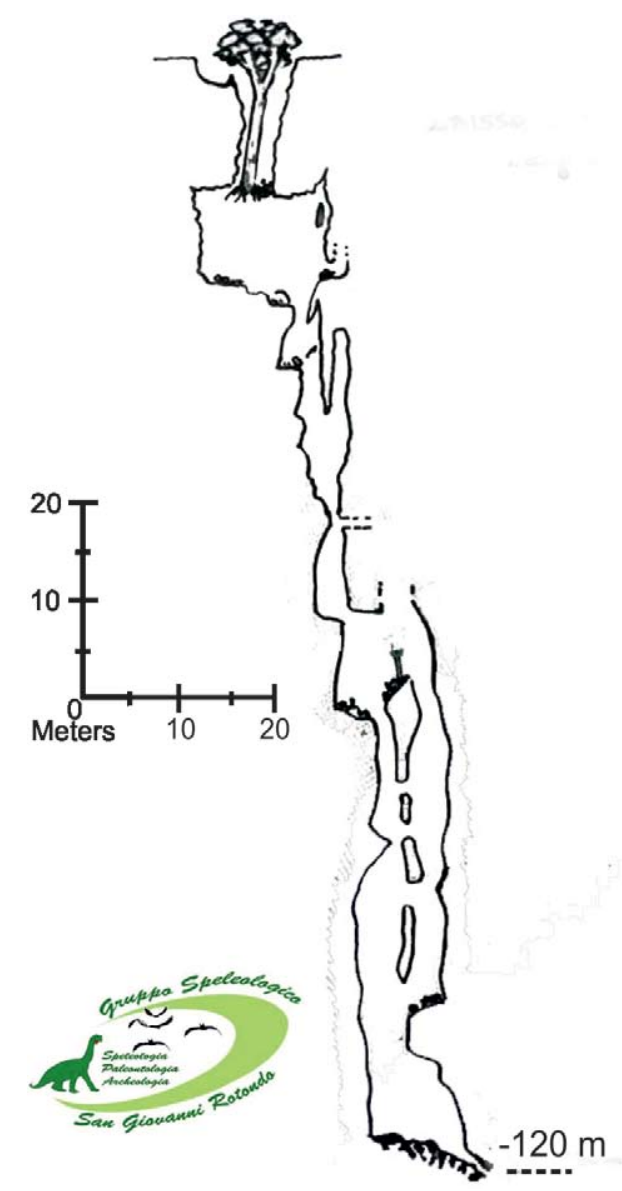

Figure 8: Profile of the Abisso San Matteo sinkhole (marked as PU 2656 in the regional register of natural caves, managed by Federazione Speleologica Pugliese, http://www.catasto.fspuglia.it), as obtained from the speleological survey (courtesy of Gruppo Speleologico San Giovanni Rotondo). The cave reaches a depth of $-120 \mathrm{~m}$ from the ground surface.

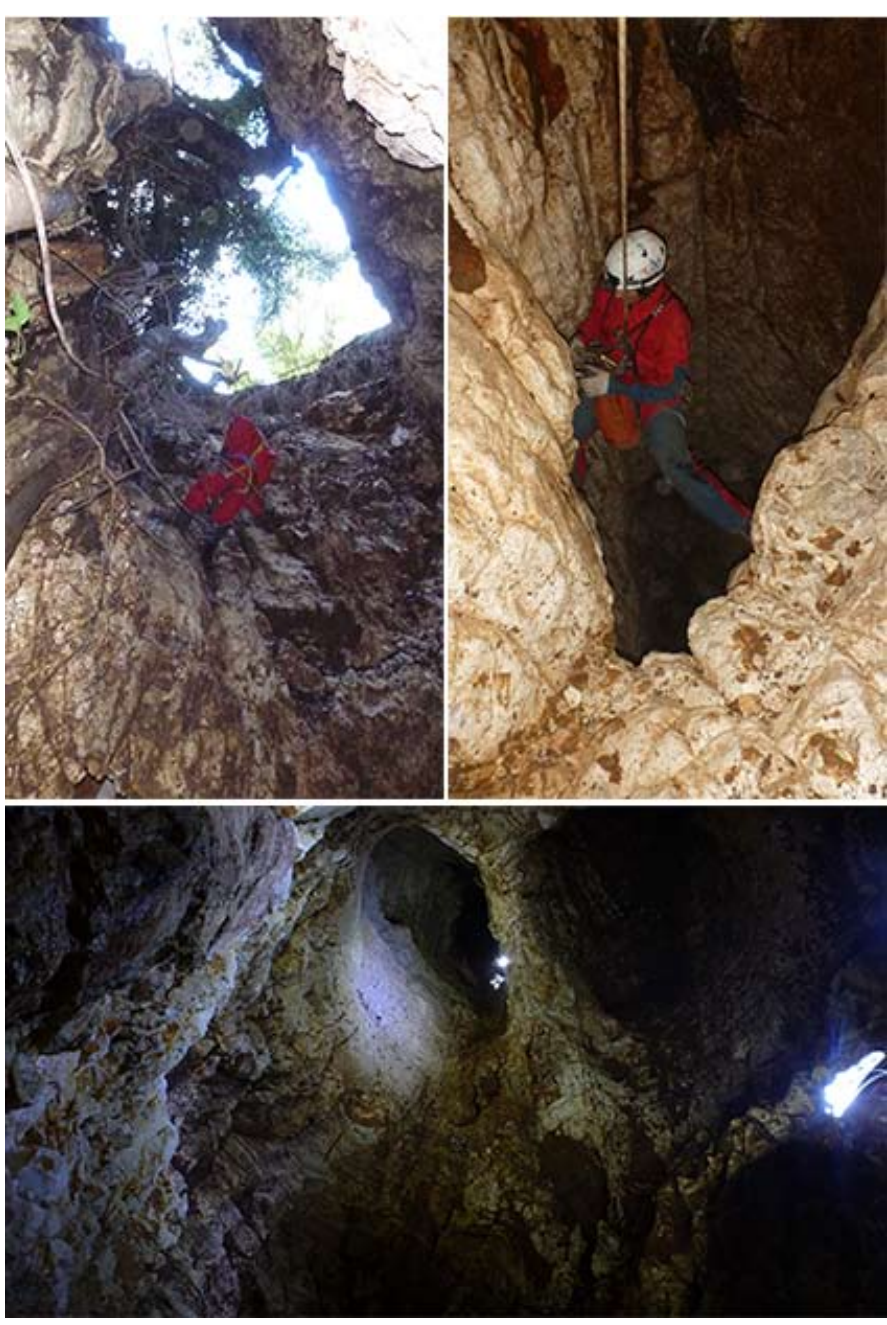

Figure 9. Series of shafts within the Abisso San Matteo sinkhole (photos courtesy of Gruppo Speleologico San Giovanni Rotondo). The photograph at the bottom is an upward view of the first $25 \mathrm{~m}$ of the cave. 


\section{Discussion}

In karst, it is not an easy matter to understand the main hydrological features at the surface and the groundwater circulation, due to peculiarity of karst terrains, and to their hydrogeological characteristics (Bonacci, 1995; Worthington, 1999; Worthington et al., 2001; White, 2002; Gunn, 2007; Palmer, 2010; Parise, 2016). This is even more complicated during heavy rainstorms and floods (White and White, 1984; Parise, 2003; Delrieu et al., 2005; Bonacci et al., 2006; Jourde et al., 2007; Delle Rose and Parise, 2010), with response to the storm that may heavily change with rainfall intensity or duration, as well as the cumulated amount of rainfall. For these reasons, it is extremely important to document any karst landscape changes occurring after significant rainstorms, both to contribute to future evaluation of the likely sinkhole hazard, and for collecting data aimed at the full comprehension of the water-flow circulation at the surface and subsurface (Parise and Pascali, 2003).

The Gargano Promontory is one of the main karst subsectors of Apulia. However, not many studies are available to provide data about origin and evolution of the karst features in the area. The information presented in this article, even though not numerous, and definitely not exhaustive, is, nevertheless, a worthy amount of data to characterize the effects of the heavy rainstorms that hit the area. Further, we were able to identify the typology of the produced sinkholes, and to link the timing of sinkhole formation to the September 2014 storm. Knowledge of the time of sinkhole occurrence is typically the most difficult information to obtain. This often hinders any possibility to link the sinkholes to triggering factors, and particularly to rainfalls (Brinkmann and Parise, 2010).

\section{Conclusions}

Data presented here, added to those already available about sinkhole chronology in Apulia (see Parise and Vennari, 2013, 2017), may help to build a sufficient amount of information to develop further studies. These can be aimed at evaluating the sinkhole hazard in the Gargano Promontory and in the entire region. Hazard evaluation is a complex task that is rarely actually reached, mostly due to lack of data about the connection between a triggering event and sinkhole occurrence.

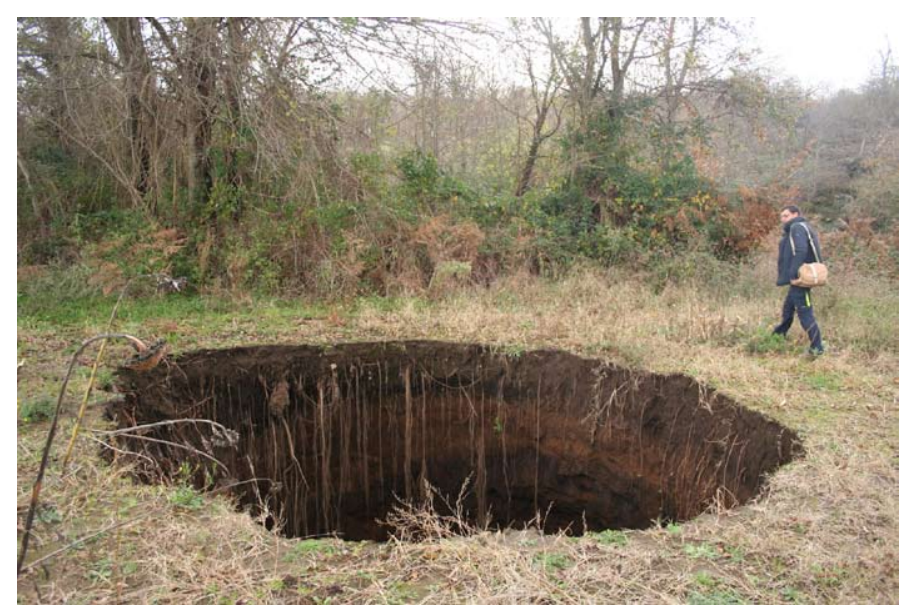

Figure 10. The main sinkhole in the San Marco in Lamis group.
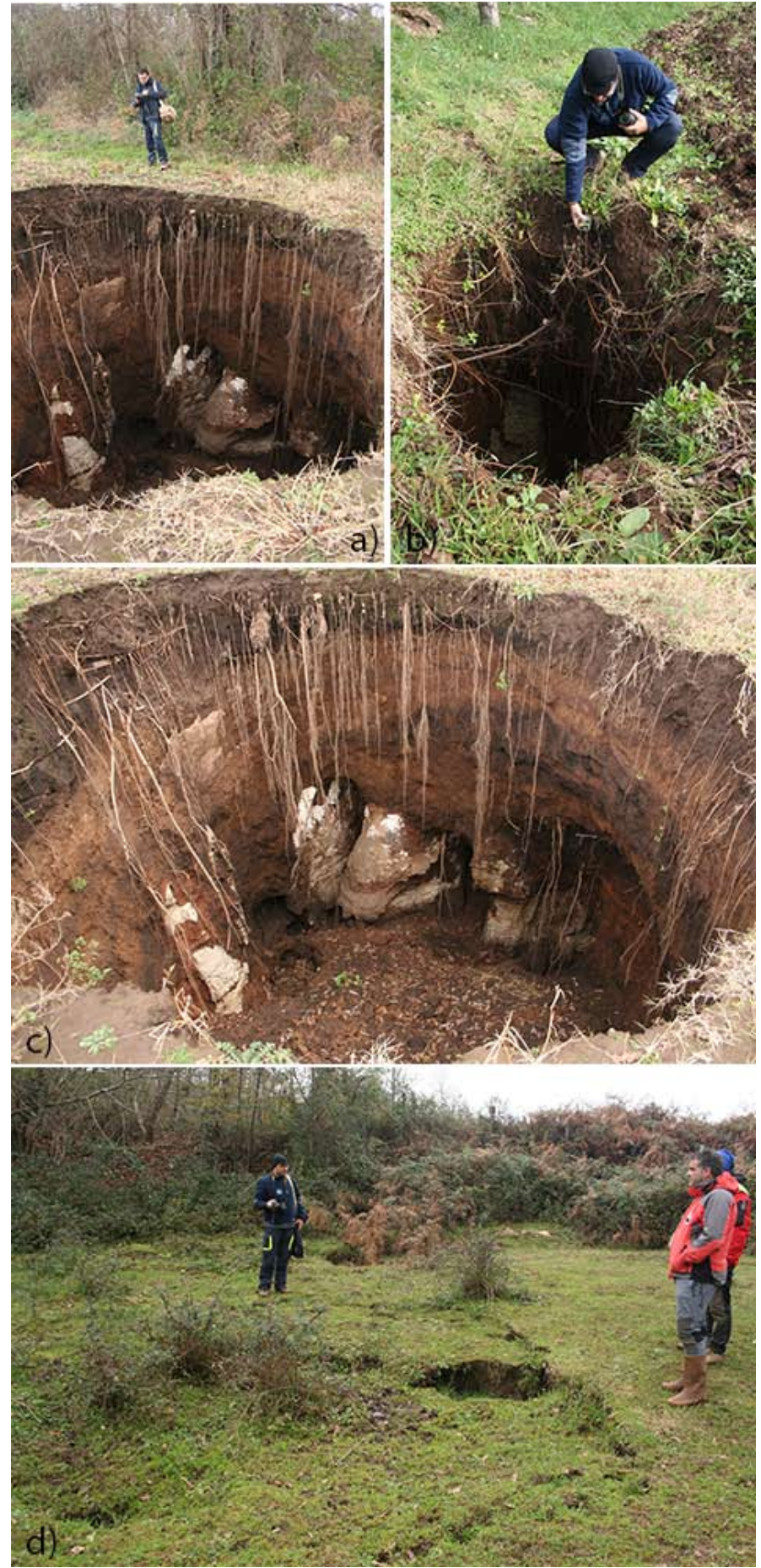

Figure 11. Sinkholes triggered by the September 1-6, 2014, intense rainfall event in the Gargano Promontory at San Marco in Lamis: a) and c) the main sinkhole of the group, $5.4 \mathrm{~m}$ deep; b) small-sized sinkhole opened at the boundary of a closed depression (person for scale); d) small-sized sinkhole within a greater depressed area, marked by lowering of the ground over an area about $25 \mathrm{~m}$ wide (person for scale). 


\section{Acknowledgements}

We thank the Civil Protection Service of Apulia Region for the rainfall data, and are extremely grateful to members of the grottos Gruppo Speleologico San Giovanni Rotondo and Gruppo Speleologico Montenero for accompanying us in the field to observe the sinkholes and for the related underground documentation.

\section{References}

Angel, J.C., Nelson, D.O., and Panno, S.V., 2004, Comparison of a new GIS-based technique and a manual method for determining sinkhole density: An example from Illinois' sinkhole plain: Journal of Cave and Karst Studies, v. 66, p. 9-17.

Basso, A., Bruno, E., Parise, M., and Pepe, M., 2013, Morphometric analysis of sinkholes in a karst coastal area of southern Apulia (Italy): Environmental Earth Sciences, v. 70, no. 6, p. 2545-2559. https://doi.org/10.1007/s12665-013-2297-z

Bautista, F., Palacio-Aponte, G., Quintana, P., and Zinck, A.J., 2011, Spatial distribution and development of soils in tropical karst areas from Peninsula of Yucatan, Mexico: Geomorphology, v. 135, p. 308-321. https://doi.org/10.1016/j.geomorph.2011.02.014

Bonacci, O., 1995, Ground water behaviour in karst: example of the Ombla Spring (Croatia). Journal of Hydrology, v. 165, p. 113-134. https://doi. org/10.1016/0022-1694(94)02577-X

Bonacci, O., Ljubenkov, I., and Roje-Bonacci, T., 2006, Karst flash floods: an example from the Dinaric karst, Croatia. Natural Hazards and Earth System Sciences, v. 6, p. 195-203. https://doi.org/10.5194/nhess-6-195-2006

Borgatti, L., Bianchi, E., Bonaga, G., Gottardi, G., Landuzzi, A., Vittuari, L., and Pellegrini, M., 2013, Sinkholes in the Po Plain as evidence of paleoliquefaction events: Rendiconti Online Società Geologica Italiana, v. 24, p. 34-36.

Bosellini, A., Morsilli, M., and Neri, C., 1999, Long-term event stratigraphy of the Apulia platform margin (Upper Jurassic to Eocene; Gargano, southern Italy): Journal of Sedimentary Research, v. 69, p.1241-1252.

Brankman, C.M., and Aydin, A., 2004, Uplift and contractional deformation along a segmented strike-slip fault system: The Gargano Promontory, southern Italy: Journal of Structural Geology, v. 26, p. 807-824. https://doi.org/10.1016/j.jsg.2003.08.018

Brinkmann, R., 2013, Florida Sinkholes. University Press of Florida, ISBN 978-0-8130-4495-8.

Brinkmann, R., and Parise, M., 2010, The timing of sinkhole formation in Tampa and Orlando, Florida: The Florida Geographer, v. 41, p. $22-38$.

Brinkmann, R., Parise, M., and Dye, D., 2008, Sinkhole distribution in a rapidly developing urban environment: Hillsborough County, Tampa Bay area, Florida: Engineering Geology, v. 99, p. 169-184. https://doi.org/10.1016/j.enggeo.2007.11.020

Brinkmann, R., Wilson, K., Elko, N., Seale, L.D., Florea, L., and Vacher, H.L., 2007, Sinkhole distribution based on pre-development mapping in urbanized Pinellas County, Florida, USA, in Parise, M., and Gunn, J., eds., Natural and Anthropogenic Hazards in Karst Areas: Recognition, Analysis and Mitigation. Geological Society, London, Special Publication no. 279, p. 5-11. https://doi.org/10.1144/SP279.2

Bruno, E., Calcaterra, D., and Parise, M., 2008, Development and morphometry of sinkholes in coastal plains of Apulia, southern Italy. Preliminary sinkhole susceptibility assessment: Engineering Geology, v. 99, p. 198-209. https://doi.org/10.1016/j.enggeo.2007.11.017

Castiglioni, B., and Sauro, U., 2000, Large collapse dolines in Puglia (southern Italy): The cases of "Dolina Pozzatina" in the Gargano plateau and of "puli" in the Murge: Acta Carsologica, v. 29, no. 2, p. 83-93.

Cooper, A.H., 2008, The classification, recording, databasing and use of information about building damage caused by subsidence and landslides: Quarterly Journal of Engineering Geology and Hydrogeology, v. 41, p. 409-424. https://doi.org/10.1144/1470-9236/07-223

Day, M., 1983, Doline morphology and development in Barbados: Annals of the Association of American Geographers, v. 73, no. 2, p. 206-219. https://doi.org/10.1111/j.1467-8306.1983.tb01408.x

De Bruyn, I. A., and Bell, F. G., 2001, The occurrence of sinkholes and subsidence depressions in the Far West Rand and Gauteng Province, South Africa and their engineering implications: Environmental \& Engineering Geoscience, v. 7, no. 3, p. 281-295. https://doi.org/10.2113/ gseegeosci.7.3.281

Delle Rose M., and Parise, M., 2002, Karst subsidence in south-central Apulia Italy: International Journal of Speleology, v. 31, no. 1/4, p. 181-199. https://doi.org/10.5038/1827-806X.31.1.11

Delle Rose, M., and Parise, M., 2010, Water management in the karst of Apulia, southern Italy, in Bonacci, O., ed., Proceedings of International Interdisciplinary Scientific Conference, Sustainability of the Karst Environment, Dinaric Karst and Other Karst Regions: International Interdisciplinary Scientific Conference, Plitvice Lakes, Croatia, 23-26 September 2009, IHP-UNESCO, Series on Groundwater, no. 2, p. 33-40.

Del Prete, S., lovine, G., Parise, M., and Santo, A., 2010, Origin and distribution of different types of sinkholes in the plain areas of Southern Italy: Geodinamica Acta, v. 23, no. 1/3, p. 113-127. https://doi.org/10.3166/ga.23.113-127

Delrieu, G., Nicol, J., Yates, E., Kirstetter, P.-E., Creutin, J.-D., Anquetin, S., Obled, C. and Saulnier, G.-M., 2005, The catastrophic flash-flood event of 8-9 September 2002 in the Gard region, France: a first case study for the Cévennes-Vivarais Mediterranean Hydrometeorological Observatory: Journal of Hydrometeorology, v. 6, p. 34-52. https://doi.org/10.1175/JHM-400.1

Denizman, C., 2003, Morphometric and spatial distribution parameters of karstic depressions, lower Suwannee river basin, Florida: Journal of Cave and Karst Studies, v. 65, p. 29-35.

De Waele, J., Gutierrez, F., Parise, M., and Plan, L., 2011, Geomorphology and natural hazards in karst areas: a review: Geomorphology, v. 134, no. 1-2, p. 1-8. https://doi.org/10.1016/j.geomorph.2011.08.001

De Waele, J., Piccini, L., Columbu, A., Madonia, G., Vattano, M., Calligaris, C., D’Angeli, I.M., Parise, M., Chiesi, M., Sivelli, M., Vigna, B., Zini, L., Chiarini, V., Sauro, F., Drysdale, R., and Forti, P., 2017, Evaporite karst in Italy: a review. International Journal of Speleology, v. 46, no. 2, p. 137-168. https://doi.org/10.5038/1827-806X.46.2.2107

Ezersky, M., Legchenko, A., Camerlynck, C., and Al-Zoubi, A., 2009, Identification of sinkhole development mechanism based on a combined geophysical study in Nahal Hever South area (Dead Sea coast of Israel): Environmental Geology, v. 58, p. 1123-1141. https://doi.org/10.1007/ s00254-008-1591-7

Farrant, A.R., and Cooper, A.H., 2008, Karst geohazards in the UK: The use of digital data for hazard management: Quarterly Journal of Engineering Geology and Hydrogeology, v. 41, p. 339-356. https://doi.org/10.1144/1470-9236/07-201

Festa, V., Fiore, A., Parise, M., and Siniscalchi, A., 2012, Sinkhole evolution in the Apulian karst of southern Italy: a case study, with some considerations on sinkhole hazards: Journal of Cave and Karst Studies, v. 74, no. 2, p. 137-147. https://doi.org/10.4311/2011JCKS0211

Fidelibus, M.D., Gutierrez, F., and Spilotro, G., 2011, Human-induced hydrogeological changes and sinkholes in the coastal gypsum karst of Lesina Marina area (Foggia Province, Italy): Engineering Geology, v. 118, p. 1-19. https://doi.org/10.1016/j.enggeo.2010.12.003

Fiore, A., and Parise, M., 2013, Cronologia degli eventi di sprofondamento in Puglia, con particolare riferimento alle interazioni con l'ambiente antropizzato: Memorie Descrittive della Carta Geologica d'Italia, v. 93, p. 239-252.

Florea, L., 2005, Using state-wide GIS data to identify the coincidence between sinkholes and geologic structure: Journal of Cave and Karst 
Studies, v. 67 , p. $120-124$.

Ford, D.C., and Williams, P.W., 2007, Karst geomorphology and hydrology. 2nd ed. John Wiley \& Sons, Chichester, U.K. https://doi.org/10.1002/9 781118684986

Fragoso-Servón, P., Bautista, F., Frausto, O., and Pereira, A., 2014, Caracterización de las depresiones kársticas (forma, tamaño y densidad) a escala 1:50000 y sus tipos de inundación en el Estado de Quintana Roo, México: Revista Mexicana de Ciencias Geológicas, v. 31, no. 1, p. 127-137.

Frumkin, A., Ezersky, M., Al-Zoubi, A., Akkawi, E., and Abueladas, A.R., 2011, The Dead Sea sinkhole hazard: geophysical assessment of salt dissolution and collapse: Geomorphology, v. 134, p. 1102-1117. https://doi.org/10.1016/j.geomorph.2011.04.023

Funiciello, R., Montone, P., Parotto, M., Salvini, F., and Tozzi, M., 1991, Geodynamical evolution of an intra-orogenic foreland: The Apulia case history (Italy): Bollettino della Società Geologica Italiana, v. 110, no. 3-4, p. 419-425.

Galve, J.P., Remondo, J., and Gutiérrez, F., 2011, Improving sinkhole hazard models incorporating magnitude-frequency relationships and nearest neighbour analysis: Geomorphology, v. 134, p. 157-170. https://doi.org/10.1016/j.geomorph.2011.05.020

Gambini, R., and Tozzi, M., 1996, Tertiary geodynamic evolution of the Southern Adria microplate: Terra Nova, v. 8, p. 593-602. doi: 10.1111/ j.1365-3121-1996.tb00789x.

Gao Yongli, Alexander, E.C., and Barnes, R., 2005, Karst database implementation in Minnesota: analysis of sinkhole distribution: Environmental Geology, v. 47, no. 8, p. 1083-1098. https://doi.org/10.1007/s00254-005-1241-2

Gunn, J., 2007, Contributory area definition for groundwater source protection and hazard mitigation in carbonate aquifers, in Parise, M., and Gunn, J., eds., Natural and Anthropogenic Hazards in Karst Areas: Recognition, Analysis, and Mitigation. Geological Society, London. 279, p. 97-109. https://doi.org/10.1144/SP279.9

Gutiérrez, F., 2010, Hazards associated with karst, in Alcántara, I., and Goudie, A., eds., Geomorphological Hazards and Disaster Prevention. Cambridge University Press, Cambridge, p. 161-175. https://doi.org/10.1017/CBO9780511807527.013

Gutiérrez, F., Guerrero, J., and Lucha, P., 2008, A genetic classification of sinkholes illustrated from evaporite paleokarst exposures in Spain: Environmental Geology, v. 53, p. 993-1006. https://doi.org/10.1007/s00254-007-0727-5

Gutiérrez, F., Parise, M., De Waele, J., and Jourde, H., 2014, A review on natural and human-induced geohazards and impacts in karst: EarthScience Reviews, v. 138, p. 61-88. https://doi.org/10.1016/j.earscirev.2014.08.002

Gutiérrez-Santolalla, F., Gutiérrez-Elorza, M., Marín, C., Desir, G., and Maldonado, C., 2005, Spatial distribution, morphometry and activity of La Puebla de Alfindén sinkhole field in the Ebro river valley (NE Spain): applied aspects for hazard zonation: Environmental Geology, v. 48, p. 360-369. https://doi.org/10.1007/s00254-005-1280-8

He Keqiang, Liu Changli, and Wang Sijing, 2003, Karst collapse related to over-pumping and a criterion for its stability: Environmental Geology, v. 43, p. 720-724.

Heidari, M., Khanlari, G.R., Taleb Beydokhti, A.R., and Momeni, A.A., 2011, The formation of cover collapse sinkholes in North of Hamedan, Iran: Geomorphology, v. 132, p. 76-86. https://doi.org/10.1016/j.geomorph.2011.04.025

Hung L.Q., Dinh N.Q., Batelaan, O., Tam V.T., and Lagrou, D., 2002, Remote sensing and GIS-based analysis of cave development in the Suoimuoi catchment (Son La - NW Vietnam): Journal of Cave and Karst Studies, v. 64, p. 23-33.

Iovine, G., Parise, M., and Trocino, A., 2010, Breakdown mechanisms in gypsum caves of southern Italy, and the related effects at the surface: Zeitschrift fuer Geomorphologie, v. 54 (suppl. 2), p. 153-178. https://doi.org/10.1127/0372-8854/2010/0054S2-0009

Iovine, G., Vennari, C., Gariano, S.L., Caloiero, T., Lanza, G., Nicolino, N., Suriano, S., Ferraro, G., and Parise, M., 2016, The "Piano dell'Acqua" sinkholes (San Basile, Northern Calabria, Italy): Bulletin of Engineering Geology and the Environment, v. 75, no. 1, p. 37-52. https://doi. org/10.1007/s10064-015-0737-6

Jourde, H., Roesch, A., Guinot, V., and Bailly-Comte, V., 2007, Dynamics and contribution of karst groundwater to surface flow during Mediterranean flood: Environmental Geology, v. 51, no. 5, p. 725-730. https://doi.org/10.1007/s00254-006-0386-y

Kawashima, K., Aydan, O., Aoki, T., Kishimoto, I., Konagal, K., Matsui, T., Sakuta, J., Takahashi, N., Teodori, S.-P., and Yashima, A., 2010, Reconnaissance investigation on the damage of the 2009 L'Aquila, Central Italy, earthquake: Journal of Earthquake Engineering, v. 14, p. 817-841. https://doi.org/10.1080/13632460903584055

Kemmerly, P.R., 2006, Modeling doline populations with logistic growth functions: Earth Surface Processes and Landforms, v. 32, p. $587-601$. https://doi.org/10.1002/esp.1420

Klimchouk, A.B., 2000, The formation of epikarst and its role in vadose speleogenesis, in Klimchouk, A.B., Ford, D.C., Palmer, A.N., and Dreybrodt, W., eds., Speleogenesis Evolution of Karst Aquifers. National Speleological Society, Huntsville, Alabama, USA, p. 91-99.

Kovacič, G., and Ravbar, N., 2010, Extreme hydrological events in karst areas of Slovenia, the case of the Unica River basin: Geodinamica Acta, v. 23 , no. $1-3$, p. $89-100$.

Lei, M., Gao, Y., Jiang, X., and Guan, Z., 2016, Mechanism analysis of sinkhole formation at Maohe village, Liuzhou city, Guangxi province, China: Environmental Earth Sciences, v. 75, 542. https://doi.org/10.1007/s12665-015-5100-5

Lollino, P., Martimucci, V., \& Parise, M., 2013, Geological survey and numerical modeling of the potential failure mechanisms of underground caves: Geosystem Engineering, v. 16, no. 1, p. 100-112. https://doi.org/10.1080/12269328.2013.780721

Lyew-Ayee, P., Viles, H.A., and Tucker, G.E., 2006, The use of GIS-based digital morphometric techniques in the study of cockpit karst: Earth Surface Processes and Landforms, v. 32, p. 165-179, doi: 10.1002/esp.1399. https://doi.org/10.1002/esp.1399

Margiotta, S., Negri, S., Parise, M., and Valloni, R., 2012, Mapping the susceptibility to sinkholes in coastal areas, based on stratigraphy, geomorphology and geophysics: Natural Hazards, v. 62, no. 2, p. 657-676. https://doi.org/10.1007/s11069-012-0100-1

Margiotta, S., Negri, S., Parise, M., and Quarta, T.A.M., 2016, Karst geosites at risk of collapse: The sinkholes at Nociglia (Apulia, SE Italy): Environmental Earth Sciences, v. 75, no. 1, p. 1-10. https://doi.org/10.1007/s12665-015-4848-y

Martinotti, M.E., Pisano, L., Trabace, M., Marchesini, I., Peruccacci, S., Rossi, M., Amoruso, G., Loiacono, P., Vennari, C., Vessia, G., Parise M., and Brunetti, M.T., 2015, Extreme rainfall events in karst environments: The case study of September 2014 in the Gargano area (southern Italy): Geophysical Research Abstracts, v. 17, p. 2683.

Martinotti, M.E., Pisano, L., Marchesini, I., Rossi, M., Peruccacci, S., Brunetti, M.T., Melillo, M., Amoruso, G., Loiacono, P., Vennari, C., Vessia, G., Trabace, M., Parise M., and Guzzetti, F., 2016, Landslides, floods and sinkholes in a karst environment: The 1-6 September 2014 Gargano event, southern Italy: Natural Hazards Earth System Sciences Discussion. https://doi.org/10.5194/nhess-2016-310

Miao Xin, Qiu Xiaomin, Wu Shuo-Sheng, Luo Jun, Gouzie, D.R., and Xie Hongjie, 2013, Developing efficient proce- dures for automated sinkhole extraction from Lidar DEMs: Photogrammetric Engineering Remote Sensing, v. 79, no. 6, p. 545-554. https://doi.org/10.14358/PERS.79.6.545

Negri, S., Margiotta, S., Quarta, T.A.M., Castiello, G., Fedi, M., and Florio G., 2015, Integrated analysis of geological and geophysical data for the detection of man-made underground caves in an area in Southern Italy: Journal of Cave and Karst Studies, v. 77, no. 1, p. 52-62. https://doi. org/10.4311/2014ES0107 
Palmer, A. N., 2007, Cave Geology. Cave Books.

Palmer, A.N., 2010, Understanding the hydrology of karst: Geologia Croatica, v. 63, p. 143-148. https://doi.org/10.4154/gc.2010.11

Panno, S.V., Wiebel, C.P., Heigold, P.C., and Reed, P.C., 1994, Formation of regolith collapse sinkholes in southern Illinois: interpretation and identification of associated buried cavities: Environmental Geology, v. 23, p. 214-220. https://doi.org/10.1007/BF00771791

Parise, M., 2003, Flood history in the karst environment of Castellana-Grotte (Apulia, southern Italy): Natural Hazards Earth System Science, v. 3, no. 6, p. 593-604. https://doi.org/10.5194/nhess-3-593-2003

Parise, M., 2008, Rock failures in karst, in Cheng, Z., Zhang, J., Li, Z., Wu, F., and Ho, K., eds. Landslides and Engineered Slopes. Proceedings 10th International Symposium on Landslides, Xi'an (China), v. 1, p. 275-280. https://doi.org/10.1201/9780203885284-c21

Parise, M., 2010, The impacts of quarrying in the Apulian karst, in Carrasco, F., La Moreaux, J.W., Duran Valsero, J.J., and Andreo, B., eds., Advances in Research in Karst Media. Springer, p. 441-447. https://doi.org/10.1007/978-3-642-12486-0_68

Parise, M., 2012, A present risk from past activities: sinkhole occurrence above underground quarries: Carbonates and Evaporites, v. 27, no. 2, p. 109-118. https://doi.org/10.1007/s13146-012-0088-3

Parise, M., 2015, Karst geo-hazards: causal factors and management issues: Acta Carsologica, v. 44, no. 3, p. $401-414$.

Parise, M., 2016, How confident are we about the definition of boundaries in karst? Difficulties in managing and planning in a typical transboundary environment, in Stevanovic, Z., Kresic, N. and Kukuric, N., eds., Karst without boundaries. IAH-Selected Papers on Hydrogeology, 23, ISBN 9781138029682, CRC Press, p. 27-38. https://doi.org/10.1201/b21380-4

Parise, M., and Pascali, V., 2003, Surface and subsurface environmental degradation in the karst of Apulia (southern Italy): Environmental Geology, v. 44, p. 247-256. https://doi.org/10.1007/s00254-003-0773-6

Parise, M., and Gunn, J., eds., 2007, Natural and anthropogenic hazards in karst areas: recognition, analysis and mitigation. Geological Society of London, special publication 279, London, $202 \mathrm{p}$.

Parise, M., and Lollino, P., 2011, A preliminary analysis of failure mechanisms in karst and man-made underground caves in Southern Italy: Geomorphology, v. 134, no. 1-2, p. 132-143. https://doi.org/10.1016/j.geomorph.2011.06.008

Parise, M., and Vennari, C., 2013, A chronological catalogue of sinkholes in Italy: The first step toward a real evaluation of the sinkhole hazard, in Land, L., Doctor, D.H., and Stephenson, B., eds., Proceedings of the 13th Multidisciplinary Conference on Sinkholes and the Engineering and Environmental Impacts of Karst, Carlsbad (New Mexico, USA), May 6-10, 2013, National Cave and Karst Research Institute, p. 383-392.

Parise, M., and Vennari, C., 2017, Distribution and features of natural and anthropogenic sinkholes in Apulia, in Renard, P., and Bertrand, C., eds., Euro Karst 2016, Neuchâtel. Advances in the Hydrogeology of Karst and Carbonate Reservoirs. Springer, p. 27-34.

Parise, M., Perrone, A., Violante, C., Stewart, J.P., Simonelli, A., and Guzzetti, F., 2010, Activity of the Italian National Research Council in the aftermath of the 6 April 2009 Abruzzo earthquake: The Sinizzo Lake case study. Proc. 2nd Int. Workshop "Sinkholes in the Natural and Anthropogenic Environment," Rome, p. 623-641.

Parise, M., Ravbar, N., Živanovic, V., Mikszewski, A., Kresic, N., Mádl-Szo"Nyi, J., and Kukuric, N., 2015a, Hazards, in karst and managing water resources quality, in Stevanovic, Z., ed., Karst Aquifers - Characterization and Engineering. Professional Practice in Earth Sciences, Springer, p. 601-687. https://doi.org/10.1007/978-3-319-12850-4_17

Parise, M., Closson, D., Gutierrez, F., and Stevanovic, Z., 2015b, Anticipating and managing engineering problems in the complex karst environment: Environmental Earth Sciences, v. 74, p. 7823-7835. https://doi.org/10.1007/s12665-015-4647-5

Polk, J.S., North, L.A., Federico, R., Ham, B., Nedvidek, D., Mc Clanahan, K., Kambesis, P., and Marasa, M.J., 2015, Cars and karst: investigating the National Corvette Museum sinkhole, in Doctor, D.H., Land, L., and Stephenson, B., eds., Proceedings of the 14th Multidisciplinary Conference on Sinkholes and the Engineering and Environmental Impacts of Karst, Rochester (Minnesota, USA), 5-9 October 2015, National Cave and Karst Research Institute, p. 477-482.

Scheidt, J., Lerche, I., and Paleologos, E., 2005, Environmental and economic risks from sinkholes in west-central Florida: Environmental Geosciences, v. 12, p. 207-217. https://doi.org/10.1306/eg.05130404009

Simone, O., and Fiore, A., 2014, Five large collapse dolines in Apulia (Southern Italy) — the Dolina Pozzatina and the Murgian Puli: Geoheritage, v. 6, no. 4, p. 291-303. https://doi.org/10.1007/s12371-014-0122-z

Tihansky, A.B., 1999, Sinkholes, west-central Florida, in Galloway, D., Jones, D.R., and Ingebritsen, S.E., eds., Land Subsidence in the United States. U.S. Geological Survey Circular 1182, p. 121-140.

Vigna, B., Fiorucci, A., Banzato, C., Forti, P., and De Waele, J., 2010, Hypogene gypsum karst and sinkhole formation at Moncalvo (Asti, Italy): Zeitschrift fuer Geomorphologie, v. 54, no. 2, p. 285-306. https://doi.org/10.1127/0372-8854/2010/0054S2-0015

Waltham, T., and Lu, Z., 2007, Natural and anthropogenic rock collapse over open caves, in Parise, M., and Gunn, J., eds., Natural and anthropogenic hazards in karst areas: recognition, analysis and mitigation. Geological Society of London, special publication 279, p. 13-21. https://doi. org/10.1144/SP279.3

Waltham, T., Bell, F., and Culshaw, M., 2005, Sinkholes and subsidence. Karst and cavernous rocks in engineering and construction. Springer Praxis.

White, W.B., 2002, Karst hydrology: recent developments and open questions: Engineering Geology, v. 65, p. 85-105. https://doi.org/10.1016/ S0013-7952(01)00116-8

White, E.L., and White, W.B., 1984, Flood hazards in karst terrains: lessons from the Hurricane Agnes storm, in Burger, A., and Dubertret, L., eds., Hydrogeology of Karst Terrains, v. 1, p. 261-264.

White, E.L., Aron, G., and White, W.B., 1986, The influence of urbanization on sinkholes development in Central Pennsylvania: Environmental Geology and Water Sciences., v. 8, p. 91-97. https://doi.org/10.1007/BF02525562

Williams, P.W., 2008, The role of the epikarst in karst and cave hydrogeology: a review: International Journal of Speleology, v. 37, p. 1-10. https:// doi.org/10.5038/1827-806X.37.1.1

Worthington, S.R.H., 1999, A comprehensive strategy for understanding flow in carbonate aquifers, in Palmer, A.N., Palmer, M.V., and Sasowsky, I.D., eds., Karst Modeling. Karst Water Institute, Special Publication. 5, p. 30-37.

Worthington, S., Ford, D., and Beddows, P., 2001, Characteristics of porosity and permeability enhancement in unconfined carbonate aquifers due to the development of dissolutional channel systems, in Gunay, G., Ford, D., Williams, P., and Johnson, K., eds., Present state and future trends of karst studies, Technical Documents in Hydrology. UNESCO, Paris, v. 49, p. 13-29.

Wu Qiusheng, Deng Chengbin, and Chen Zuoqi, 2016, Automated delineation of karst sinkholes from LIDAR-derived digital elevation models: Geomorphology, v. 266, p. 1-10. https://doi.org/10.1016/j.geomorph.2016.05.006

Zini, L., Calligaris, C., Forte, E., Petronio, L., Zavagno, E., Boccali, C., and Cucchi, F., 2015, A multidisciplinary approach in sinkhole analysis: The Quinis village case study (NE-Italy) Engineering Geology, v. 197, p. 132-144. https://doi.org/10.1016/j.enggeo.2015.07.004 